Article

\title{
Projective Verse: The Spiritual Legacy of the Beat Generation
}

\author{
Paul E. Nelson $\mathbb{D}$
}

SPLAB (Seattle Poetics LAB), Seattle, WA 98118, USA; splabman@gmail.com; Tel.: +1-206-422-5002

Received: 25 September 2018; Accepted: 17 October 2018; Published: 22 October 2018

\begin{abstract}
Allen Ginsberg's poetry, poetics or cultural activism; Jack Kerouac's prose, poetry and his method of composition; Gary Snyder's environmental and Buddhist consciousness and bioregional ethos, or the opening made by the Beats for Eastern spirituality in the west are of intrinsic value and will be for generations, this paper seeks to posit that it is Michael McClure's use of Projective Verse, that future generations of writers and readers will come to appreciate as that movement's spiritual legacy.
\end{abstract}

Keywords: Michael McClure; Beat Generation; Charles Olson; Allen Ginsberg; Jack Kerouac; Spontaneous Bop Prosody; Projective Verse; Alfred North Whitehead; Robert Duncan; Hua-yen Buddhism

\section{Introduction}

"The fashion of Zen ... is a symptom of western man's desperate need to recover spontaneity and depth in a world which his technological skill has made rigid, artificial and spiritually void."

-Thomas Merton

Although the velocity of our time makes the quality of our decades seem much shorter than in past eras, it will likely be the twenty-second century before an accurate summation is available on the mid-twentieth century literary movement known as the Beat Generation. While Allen Ginsberg's poetry, poetics or cultural activism; Jack Kerouac's prose, poetry and his method of composition; Gary Snyder's environmental and Buddhist consciousness and bioregional ethos, or the opening made by the Beats for Eastern spirituality in the west are of intrinsic value and will be for generations, this paper seeks to posit that it is Michael McClure's use of Projective Verse, that future generations of writers and readers will come to appreciate as that movement's spiritual legacy.

Projective Verse is a method (a suggestion, McClure calls it ${ }^{1}$ ) offered by Charles Olson in 1950. Olson is most often associated with the Black Mountain School of poetry, based on his tenure at that iconic educational institution and the inclusion of his work in the Black Mountain Review, the seminal publication associated with the college. His use of Alfred North Whitehead's philosophy allowed him to create an organismic (non-mechanistic) method and McClure has perfected it better than any other poet has in over fifty years of practice.

Michael McClure is a poet, essayist, and playwright associated with the Beat Generation, given his associations with Ginsberg, Kerouac, Gary Snyder, Philip Whalen, and other poets associated with the Beats. Born in Kansas, raised there and in Seattle, McClure has been part of the San Francisco Bay

1 Via telephone conversation with the author. 
area literary community since the mid-fifties, studied with Robert Duncan, has published over forty books of poetry and essays. His performances range from the legendary Six Gallery reading in October 1955, where Allen Ginsberg recited "Howl" to Martin Scorsese's The Last Waltz where he recited from The Canterbury Tales, to collaborations with Doors keyboardist Ray Manzarek and contemporary composer Terry Riley. He was fictionalized in Jack Kerouac's novel Big Sur, co-wrote the Janis Joplin's hit "Mercedes Benz," fought censorship laws with his Obie winning play The Beard and received the Obie Award for Best Play, for his work Josephine: The Mouse Singer.

Even though McClure was friends with Kerouac, it was the method proposed by Olson that McClure would adopt and perfect in sixty years of use. It is a method similar to but deeper than Kerouac's Spontaneous Bop Prosody and aligned most with those of Black Mountain School. It has, as its foundation, a fascination with biology and is deeply influenced by Hua-yen Buddhism and Whitehead's organismic philosophy, which reads as prophetic in our hyper-materialist/ industry-generated culture age. A "use of speech at its least careless and least logical" as Olson suggested Projective Verse could be, McClure's shortens the distance between physiology and poetry, creating a gesture as fully-embodied as any major Twentieth Century poet.

\section{Methods}

Olson's manifesto was first published in 1950 in Poetry New York. A year later, a large section of it was published in William Carlos Williams' autobiography. At first glance, it has much in common with Kerouac's method, but the differences are key. Olson, like Kerouac, called for a quick process that limits the ability of the editor's mind to impede the flow,

ONE PERCEPTION MUST IMMEDIATELY AND DIRECTLY LEAD TO A FURTHER PERCEPTION. It means exactly what it says, is a matter of, at all points (even, I should say, of our management of daily reality as of the daily work) get on with it, keep moving, keep in, speed, the nerves, their speed, the perceptions, theirs, the acts, the split second acts, the whole business, keep it moving as fast as you can, citizen. And if you also set up as a poet, USE USE USE the process at all points, in any given poem always, always one perception must must must MOVE, INSTANTER, ON ANOTHER! (Olson 1997, p. 240)

This is not unlike Kerouac's suggestion in the novel Desolation Angels,

I was originating (without knowing it, you say?) a new way of writing about life, no fiction, no craft, no revising afterthoughts, the heartbreaking discipline of the veritable fire ordeal where you can't go back but have made the vow of 'speak now or forever hold your tongue' and all of it innocent go-ahead confession, the discipline of making the mind the slave of the tongue with no chance to lie or re-elaborate ... (Kerouac 1995, p. 256) ${ }^{2}$

But Olson knew that the best way to tap into deeper fields of energy was to go back to the oldest method of composing poetry in the English language, ${ }^{3}$ poem as thing received; composition as recognition,

From the moment he ventures into FIELD COMPOSITION—puts himself in the open-he can go by no track other than the one the poem under hand declares, for itself. Thus he has to behave, and be, instant by instant, aware of some several forces just now beginning to be examined. (It is much more, for example, this push, than simply such a one as Pound put, so wisely, to get us started: "the musical phrase," go by it, boys, rather than by the metronome). (Olson 1997, p. 240)

2 Interesting to read the notion of making the mind "the slave of the tongue" and contrast that with Traditional Chinese Medicine in which the tongue is the outlet of the heart.

3 https://www.thenation.com/article/angels-radios-rainer-maria-rilke/. 
This is a significant difference between the methods of Olson and Kerouac. Whereas Kerouac (and Ginsberg's poetry, take "Howl" for example) was about how to spontaneously organize verse based on memory of personal experience, Olson suggested the poet in composing go beyond conscious knowledge; develop a method of intuition that would be an embodied process based on a combination of syllable and breath line,

the HEAD, by way of the EAR, to the SYLLABLE

the HEART, by way of the BREATH, to the LINE (Olson 1997, p. 242)

Kerouac, on the other hand, summarized his narratives as "remembrance ... written on the run" (Hrebeniak 2006, p. 151). Or, in his "Essentials of Spontaneous Prose", in the section titled "Scoping" he wrote:

Not 'selectivity' of expression but following free deviation (association) of mind into limitless blow-on-subject seas of thought, swimming in sea of English with no discipline other than rhythms of rhetorical exhalation and expostulated statement, like a fist coming down on a table with each complete utterance, bang! (the space dash)-Blow as deep as you want-write as deeply, fish as far down as you want, satisfy yourself first, then reader cannot fail to receive telepathic shock and meaning-excitement by same laws operating in his own human mind.

Kerouac's method was hugely influential on the young Allen Ginsberg and in a 1963 letter to Denise Levertov, Robert Duncan outlined the difference between what he termed "the conventional poet", "the free-verse poet" and "the organic poet." Duncan used Ginsberg's "Howl" as an example of "free verse." Duncan writes,

... the poem does not find or make but expresses, and the poem has its virtue in the ecstatic state or emotional state aroused by rhythms and rime even, where the poet can pour forth what he feels// and/or God speaks through the poet once his voice is free. (Duncan and Levertov 2004, pp. 407-8)

Duncan could very well have been describing Kerouac's "scoping" notes, or anything from "Essentials of Spontaneous Prose," but in outlining what he and Levertov agreed for a time to term "organic' he (they) illustrated a method of composition which for the purposes of this argument is considered synonymous with "projective" and which they felt was a deeper gesture than "free verse." The "organic poet" is discovering content during the act of composition, a process involving full use of the body and not simply the intellect. Levertov would say "form is never more than a revelation of content" whereas Kerouac and Ginsberg already had a notion of what their content was, or so went the argument of Levertov and Duncan. The poem's content was clear before the act of composition. In the case of "Howl" it was the state in post-war U.S. culture of the state of his friends who owned the "best minds of my generation" and how they were being "destroyed."

It is not coincidental that Olson's subtitle, Composition by Field, is referenced again in the paragraph cited above, the same paragraph that refers cryptically to the projective poet being "aware of some several forces just now beginning to be examined." It was as early as 1943 that Williams was making a reference to poetry being part of the field of influence. On 26 October 1943, in a talk given at the New York Public Library, Williams stated that the war was the "first and only thing in the world today" and that poetry was not an escape from that reality but a "different sector of the field" (Mariani 1982, p. 483). Five years later at the University of Washington, he elaborated in a talk entitled "The Poem as a Field of Action." He cited the (then) recent developments in physics as precursors to the developments in verse, although he was already working in this projective manner. Not until 1948 did he begin to articulate the how of it. It would be Olson two years later to more fully articulate this revelation.

It was not until early in the twenty-first century that Rupert Sheldrake (2003) was able to articulate a branch of field theory that he developed under the appellation morphogenetic fields, 
" ... the coming into being of form (from the Greek morphe = form + genesis = coming into being)" (Sheldrake 2003, p. 275). "Matter is no longer the fundamental reality, as it was for old-style materialism. Fields and energy are now more fundamental than matter. The ultimate particles of matter have become vibrations of energy within fields." (Sheldrake 2003, p. 4)

There is no question in my mind that this is the stance toward reality that Olson was referring to in the paragraph cited above. The notion that fields, energy and the relationships which are affected by same, are more relevant than the things of Newtonian science. This is where Olson's chief source enters.

\section{Whitehead}

For Whitehead, the fundamental elements of the universe are "occasions of experience." According to this notion, what people commonly think of as concrete objects are actually successions of occasions of experience. Whitehead's occasions of experience are interrelated with every other occasion of experience that precedes it in time. Inherent to Whitehead's conception is the notion of time; all experiences are influenced by prior experiences, and will influence all future experiences. This process of influencing is never deterministic; an occasion of experience consists of a process of prehending other experiences, and then a reaction to it. In other words, for Whitehead, the universe is incomplete and in process, and past events have an effect on present ones.

So, we get to another key difference in the poetics of Olson and Kerouac/Ginsberg. In the concept of prehension, one goes beyond the mere noticing Ginsberg is famous for suggesting when he says poets are people who "notice what they notice" (Ginsberg 1994, p. 478). Prehension is a deeper engagement, one which we have all experienced in the act of sacred devotion to a moment, whether that be taking in a lover's eyes during the sensual act, fully breathing in the first lilac smell of the new season, or watching the perfect drive in golf sail along, gently rising until settling in the middle of the fairway 225 yards away, as the muscle memory of how the club feels in your hands remains vivid.

These experiences of vividness go beyond noticing. They are prehension; acts in which our consciousness for a time actually merges with the "object." I merge with the lover, smell the lilac, experience the golf ball as an extension of my own consciousness and, as such, for a time create a greater field of energy; a deeper occasion of experience. Robert von Hallberg understands this process of becoming, writing in his book, Charles Olson: The Scholar's Art, that,

Whitehead's analysis of the process of concrescence rests on the principle, endorsed by Olson, that the past is alive in the present ... today is not necessarily in Whitehead's view, a dilution of yesterday, because the process of concresence includes an element of novelty that can make for progress. When subject and object prehend each other, they are both transformed, made new, sometimes for the better. (von Hallberg 1978, p. 103)

Note the emphasis on objects in Olson's Projective Verse essay and a notion that if the poet employing Projective Verse, "stays inside himself, if he is contained within his nature as he is participant in the larger force, he will be able to listen, and his hearing through himself will give him secrets objects share" (Olson 1997, p. 247). This is no doubt alluding to Whitehead. Olson also noted how the content changes while engaged in the projective method because practicing this method "leads to dimensions larger than the man." Again, von Hallberg on Whitehead,

Each actual entity is, in Whitehead's system, a process, first a process of becoming itself and then of becoming every other actual entity. According to his interpretation of the theory of relativity, no two actual entities are unrelated; each actual entity "feels" every other actual entity. His term for this "feeling" is "prehension." One actual entity can prehend another. one actual entity transmits itself-thereby extends its life—to another ... (von Hallberg 1978, p. 86)

In the introduction to his book Mysteriosos, McClure suggests, "A poem is a porthole of consciousness and experience, whether opening to the feeling of blood pulsing in the wrist, or the taste 
of a red-black cherry, or the sound of a rock being placed on a table." (McClure 2010, p. ix) Later in that same introduction he writes:

The rain became monumental and proportionless-I felt pliant and myriad-minded, and sensed sugars of the earth turning under the loam where the neighborhood deer had been walking in the night. The moment morphs into an airplane flight and then I am on a beach, in a favorite place near the Mayan ruins in Tulum, Yucatán. There are high green waves and an osprey flies in low circles, screaming, while I hold a handful of sand and see faces on the grains. The synaptic tracery of my nervous system coheres with the moment. Life goes on like this. (McClure 2010, p. x)

This is certainly deeper than a recall of experience, even if the memory rises to the level of "photographic." (mine doesn't). Not only is this deeper, not only does it engage fields and entities outside the "self" (although that notion becomes problematic, especially when we consider the quantum physics notion of non-locality and Whitehead's notion of actual entities), but it enables us to experience and begin to develop a preference for this deeper mode of being. We create an attractor field that begins to seek out successively deeper experiences, or as McClure said in his 1975 poem Rare Angel, "we swirl out what we are and watch what returns." This depth is what is engaged and made possible by prehension.

When we think of the publication year of Rare Angel, 1975, we might see just how much McClure went beyond Kerouac and had intuited the notions of Olson just five years after Olson's death and six years after Kerouac's.

\section{Beyond Olson}

In Charles Olson and Alfred North Whitehead: An Essay on Poetry by Shahar Bram, the author suggests that for Olson,

... poetry is not a poem: the name of an object, a finished aesthetic object, the outcome of a process is negligible. Rather, the poem is poesis; the process of creation and the poem are, at most, two names or two perspectives for contemplating the same activity, the creativity of a human being in the world ... (Bram 2004, p. 12)

It is telling that Olson took his process as far as he could and intuited that he needed another ten years to complete his work (Boer 137, quoted in (Blaser 2006, p. 196)). In Bram's essay he suggests,

Whitehead "bestows a new, more 'open' content on the concept of causality: the macroscopic process is conditioned by the past, but is open to changes suggested by the present with its new 'prehensions.' The subject re-enacts the world and grows with it". (Bram 2004, p. 83)

In a 1995 interview with McClure, about his use of Projective Verse in the book Three Poems and alluding to Whitehead's notion of prehension, he stated,

These three poems are unchanged. They're [composed] spontaneously, and they are as they were written, and each one is a kind of a spiritual challenge. Part of the adventure of the consciousness that's taking place there is, I may not change it. I mean, I do not allow myself to change it. And that doesn't mean that it's a grueling or excoriating task that I've laid upon myself but a very sweet possibility of taking a trip through experience that I've never taken before. Now, the poem does not really necessarily come from me. With projective verse, the inspiration for the poem can be outside of you, or it could be inside of you. It could be a perception or an act, or a memory, or a piece of consciousness. Let's say it was a vase of incredibly beautiful irises. Then I look at that vase of irises and/or touch it or I smell it. It's not just looking at it. I'm aware. I have the perception in the real world of that vase of irises. It becomes part of me, of the physical being, and then it sort of like 
rebounds, following my breath line onto the page and is arranged on the page in terms of my breath line, and what I'm really listening to as I write it, it's not metrical foot like, you know, light, heavy, light, heavy, light, heavy, or any given count, but I'm listening to syllables as it happens. So you see, it's less like I'm dragging something up out of myself than it is like acting in the world, like the painters that I spoke of. [Jackson Pollock].

PAUL E. NELSON: And spontaneous creation, it's improvisation, just like jazz artists.

MICHAEL McCLURE: It's improvisation, yeah.

So here is a process which is consistent with a cosmology, in fact IS a cosmology. Given another ten years, or more, Olson's work may have become even more profound; his gesture more humble. But McClure was a young man when first exposed to this method as a theory AND an experience, having met Olson and having studied with one of the poets most helpful in expanding Olson's theories, Robert Duncan. McClure studied with Duncan at San Francisco State in the early 1950s and it was not long after that when Duncan, in correspondence and collaboration with Denise Levertov, was able to understand the difference between the Open Form of Ginsberg (and by extension, Kerouac) and the deeper Organic form he and Levertov were after.

For Duncan, the important distinction was not between poets he called "Conventional" and poets concerned with innovation. Since his writing in the early 60s, there has been an explosion of MFA programs and the conventional writing usually promulgated by those institutions. The split between the New Critics and the New American Poetry has been covered extensively. But what has received less attention is the difference between Free Verse poets and those Duncan and Levertov, for a time were calling Organic. (This is the term I came to prefer because of the corresponding notion of an organismic cosmology.) The differences, cited by Duncan in collaboration with Levertov are:

Free Verse poet: the universe and man are free only in nature which has been lost in civilized forms. The poet must express his feelings without the trammel of forms. The poem does not find or make but expresses ... Free verse just doesn't believe in the struggle of rendering in which not only the soul but the world must enter into the conception of the poem.

(Ginsberg's "Howl” is one of Duncan's examples of free verse.) For the Organic Poet,

... the universe and man are members of a form. Freedom lies in the apprehension of this underlying form, towards which invention and free thought in sciences alike work. All experience is formal-We feel things in so far as we awake to the form. The form of the poem is the feeling (and where form fails, feeling fails.) (Duncan and Levertov 2004, pp. 405, 407-8)

The key here is that the authority, when one composes in this manner, increasingly becomes one's Self, which given the notion of non-locality may be more complicated to source ${ }^{4}$. The authority is not a text, sacred or otherwise, as it often was for Kerouac. (In fact, with Kerouac, a little more experience in the Zen tradition, rather than writing about said theory, would have gone a long way toward making his last years less torturous, his gesture more supple.) Nor is the authority the guru espousing such texts and experiences, as Ginsberg's unfortunate rationalization of some of the more reprehensible acts of Chogyam Trungpa Rinpoche would indicate. ${ }^{5}$

Though texts, sacred or otherwise, are certainly legitimate sources for the organic poet-especially as they relate in the poet's mind while composing to memory or phenomenology-the authority is something greater. That mind in the act of composing itself goes beyond the "self," non-local certainly, which makes the act of composing organic poetry akin to psychoanalysis. This allows the poem's

4 One Jung scholar suggests Jung's works define and describe this psychic structure, forming the foundation for 20th century discussion, theorizing and a whole therapeutic methodology.

5 (See Ed Sanders' The Party: A Chronological Perspective on a Confrontation at a Buddhist Seminary or Tom Clark's The Great Naropa Poetry Wars for more details on the main incident to which I refer.) 
meaning(s), as Peter O'Leary in his book on Duncan proposes, to be "somewhere underneath or outside, in an extra-symbolic mind: a gnostic, creative presence into whose focus the willing reader ascends" (O'Leary 2002, p. 27).

McClure did not make the mistake of surrendering his power to a guru or any similar entity. The increased development in his intuition honed over decades of experience, allowed him to channel into his verse the perceptions that are available when one engages prehension, the stronger energy fields available to the poet working, in Olson's words, in dimensions larger than the man. At 77 (at this 2010 writing) McClure's had a considerably longer time to master this method. While Olson may have had 25 years of practice (having become a poet later in life), McClure has been writing projectively since the 1950s. In addition, the process of enacting deeper fields and using negative prehension, or consciously AVOIDING engagement with certain fields and entities, he's been able to USE the process to deepen his own perception, which is the quality we're after in verse after all, yes? He's also been able to establish a Zen practice that informs his poetic practice and vice versa. (See his Dharma Devotions as a vivid example of this). And his study of Hua-yen Buddhism has allowed him to understand how that tradition goes beyond Whitehead in its understanding of how future events affect present ones. More on Hua-yen later.

So, we have here a method that is as intellectual as one can be (the HEAD, by way of the EAR, to the SYLLABLE) but also engaged with a much stronger intelligence center (the HEART, by way of the BREATH, to the LINE). It is by engaging this combination of Mind and Heart that McClure has given us an authentic poetic gesture (and playwriting, which engages projective verse as well) but also a deepening of Olson's poetic method which he intuited had more energy (and possibilities) than what he was seeing in Kerouac or Ginsberg, as interesting and relevant as they were to 20th Century verse.

\section{Least Careless and Least Logical}

Olson's suggestion for moving verse into the postmodern realm was to engage speech at the "least careless and least logical" by paying close attention to the syllables while composing. "Listening for the syllables must be so constant and so scrupulous, the exaction must be so complete, that the assurance of the ear is purchased (Olson 1997, p. 241)." While the eye can take in much more information than the brain can process, the ear works at the same speed as the mind.

The act of composing is "recognition," Olson says, and objects encountered in the act of composing "must be treated exactly as they do occur therein." This is where the mind becomes the universe's nexus for the body's proprioception. (Proprioception: the sense of the relative position of neighboring parts of the body.) Here is where the elements of the field (the pattern, we can say) are recognized and the genius of the poem comes into being. Surely the bloodline patterns heretofore ignored will rise up over and over until they are addressed, transcended. This is what McClure (and Keats before him) recognized as the practice of soul-building. If we imagine for a moment that we are not given a soul, but given the opportunity to build one, we can better understand some of the monsters of our time and, hopefully, not re-elect them!

When the act of composing becomes an integral part of a soul-building practice (and usually accompanied by other practices, such as meditation, yoga, divination,) the poet becomes much less concerned with outside validation. After all, when you are dealing with an intelligence greater than yourself and you have tapped into that on a deep level, there is little more satisfying. And the intelligence greater than one's self is surely a manifestation of a concept of mind that is non-local, not centered in the brain of the poet, but something considerably beyond that. McClure's resonance with Olson and Duncan's poetics attracted him to the concept of projective verse at an early age, yet he has expanded on their notions of how advances in science resonate with this poetics. Originally from his long poem "Dolphin Skull" and "grafted" (in his words) onto a new poem "Dear Being": 


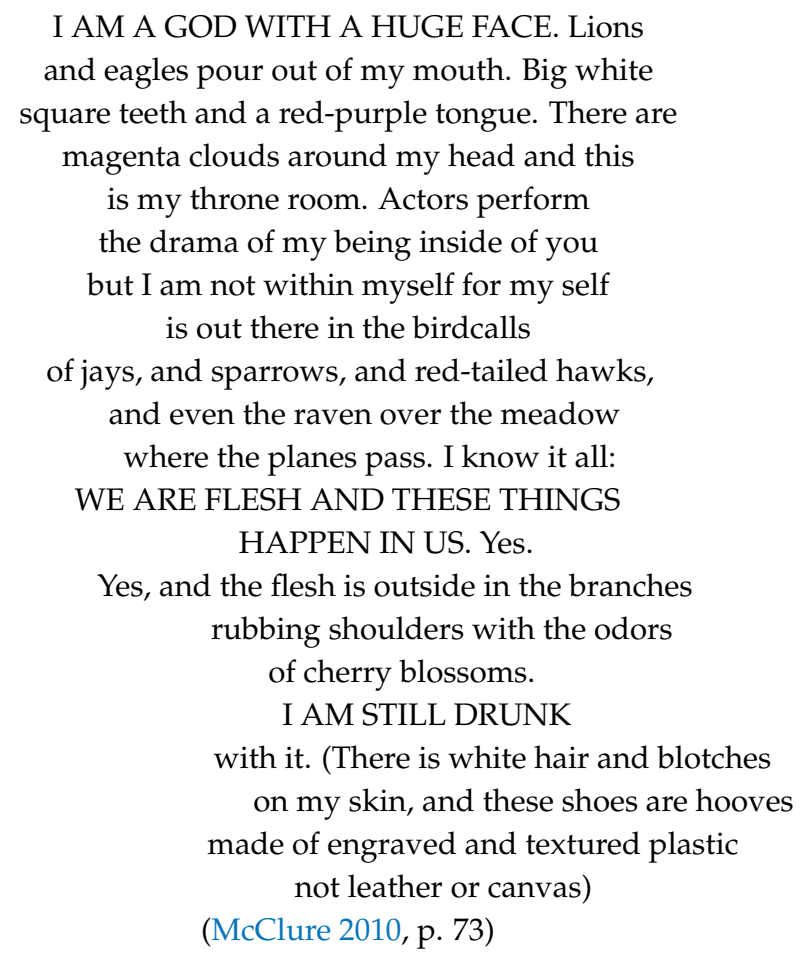

The goal of McClure's poetry practice is a sharpening of perception. (He might call it "soul-building.") His study of biology has led him to conclude many things that give his work depth and energy. In his book of essays Scratching the Beat Surface he gives us clues as to that depth when he writes,

A way of seeing an organism, other than a lump or bulk of self-perpetuating protoplasm (and there's nothing wrong with that), is the view that the organism is, in itself, a tissue or veil between itself and the environment. And, it is not only the tissue between itself and the environment-it is also simultaneously the environment itself. The organism is what Whitehead and Olson would think of as a point of novelty comprehending itself or experiencing itself both proprioceptively and at its tissues edges and at any of its conceivable surfaces. There is, in fact, a central force in the organism and it IS the environment. (McClure 1994, p. 44)

So to close the distance, McClure soon in his writing life adopted Olson's projective method and adapted it in his own way. One example is McClure's response to Robert Creeley's dictum, quoted in Projective Verse, that "form is never more than an extension of content." McClure agrees with Creeley in Scratching the Beat Surface but notes,

Even when form was redefined as an extension of content it still carried limitations. As I worked with plays and essays, I found a writhing multidimensionality of thought. As my knowledge of biology expanded, I was not content with critical descriptions and analyses of literature. They were confined to reason and logic. Yet, reason and logic, in their usual manifestations, create a veneer over potent forces that are not yet faced in the art of Poetry. When I was studying Olson's poetry a poem grew in my notebooks as I have heard that some Beethoven compositions grew: a line would occur-I'd try it with other lines-more would accrue to it. I would take a section and more would be added and discarded. At the end, rather than a tortured and studied poem, it felt like my most sudden thought. I had carved through to reach spontaneous thought and to let it speak as it might if it had been written spontaneously. (McClure 1994, p. 85) 
In McClure's practice the poem is, itself, physiological, an appendage of the body, or even an organism. In the preface to Three Poems he notes each is, "Like a living being with eyes and ears and fingers" (McClure 1995, p. xv). Using the projective method, engaged with the myriad resonances outside of the poet, bringing certain ones in via the prehension engaged in this method, the content changes, as Olson noted. This is where pattern recognition comes in. The poem as a field of energy brings in the information and each thing is a symbol, a sign, a message of some sort. Don't like the signs coming in? Change the observer and the things change. The organism evolves via negative prehension, a rejection of that which does not serve the organism seeking its highest state. A new occasion of experience builds on previous occasions. After 55 years of training his ear, his perception, his sensorium, his consciousness, McClure's mature poetry (especially after 1995) allows readers the benefits of a consciousness at play with the beauty of existence; a hungry mammal delighted by the sea of luxurious smells, the touch of silk sheets, taste of hot matcha tea on the tongue, the mist in the antlers of the deer on the hill, or the sound of Theolonious Monk plinking out his twist on the melody of Duke Ellington's "It Don't Mean a Thing if it Ain't Got That Swing".

Projective Verse is the most open of literary practices, and when we become open (with clear and healthy boundaries) the world's beauty is found in some unlikely places. Can one see the poignancy in assassination by a flaming tire around the neck? In the eyes of starving families? My sister-in-law has a habit of giving me gifts of family photographic collages, in books and DVD form. I see these and weep and she's afraid that she has upset me, but for the poet deep FEELING is the quest. We seek to feel deeply and experience fully all of life's offerings.

Of course we don't want to stay in grief mode for too long. Local Indians have a practice of doing a ritual one year after the death of a loved one as if to say now is when the grieving must stop, but poetry without feeling might as well be composed by computers, no matter the intellect at work. McClure knows certain images may be seen as horrific, but are beautiful at the same time and avoiding them is like cutting off an arm or finger. This is the essence of a sensorium that understands interconnection on a deep level, fathoms beyond theory. Steeped in deep embodied experience.

\section{Hua-Yen Buddhism}

The word Cosmology comes from the Greek kosmos, "universe", and logia, "study". So, it's the study of the Universe in its totality, and by extension, humanity's place in it. But if you combine the words cosmic and ecology, you could get the same word, cosmology. Francis Cook uses the phrase cosmic ecology early in his book Hua-yen Buddhism: The Jewel Net of Indra (Cook 1994).

McClure cites Hua-yen Buddhist thought as being an inspiration for his later poetry (see Three Poems) and we can find ample evidence of this if we know what to look for. One of McClure's chief sources for this philosophy is Cook's book. Hua-yen Buddhism is described as "triumphantly syncretic" and the founders of what became a school of Buddhist thought were attempting a grand syncretism of many different strands of Buddhist thinking (Cook 1994, p. 25).

McClure uses images from Indra's Net as a metaphor for the universe being made up of a net of infinite size with jewels at each intersection of the net, and each jewel reflecting every other jewel and thus said to be the same as every other jewel:

This is all a string of pearls

with reflections of reflections in the opulent

glimmering surface of endless flaws

making a surface

for the fingertips to touch

while remembering perfumes.

These are shadows of the wisps of nothingness

(McClure 1995, p. 35 )

Or, as McClure says in his latest book, 


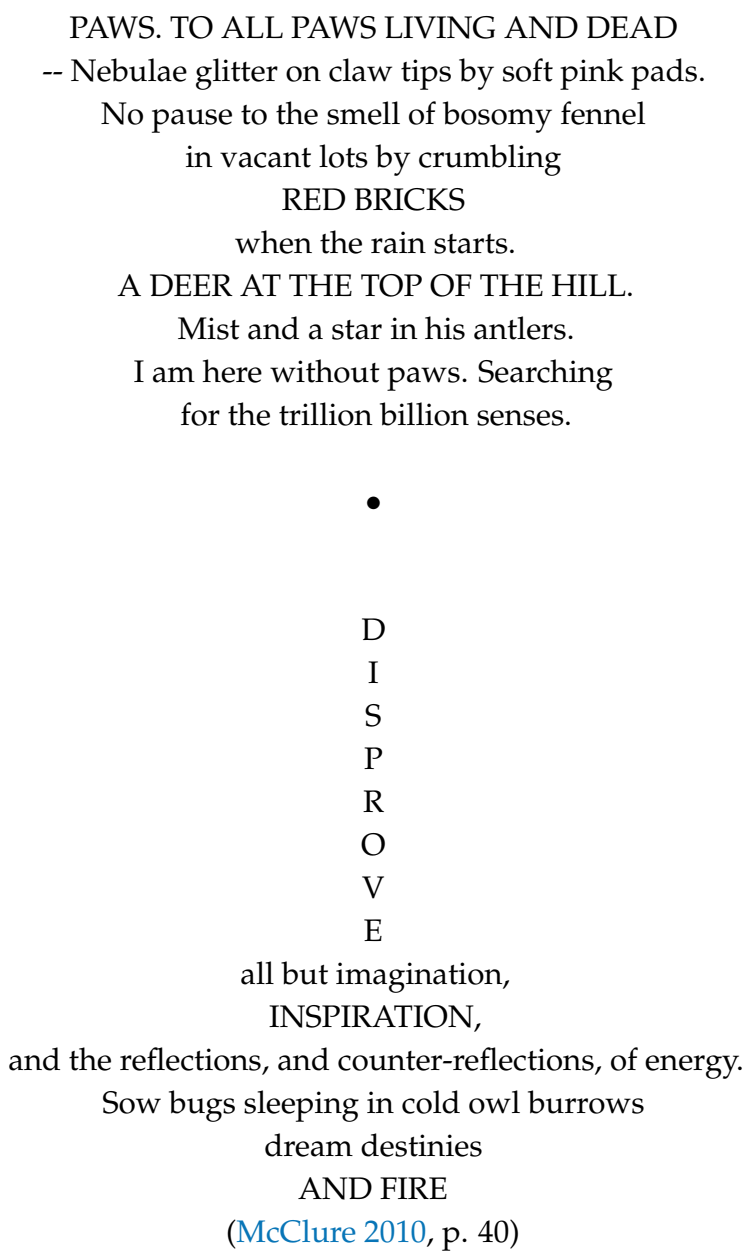

The "reflections, and counter-reflections, of energy" are the manifestations of Indra's infinite net. WE are those manifestations and every act takes us closer to the truth inherent in McClure cosmology that all consciousness is interconnected, that our human acts are only as significant as the mist and stars in a deer's antlers and even sow bugs sleeping in owl burrows. That we are connected to all that has been here before us and our acts influence future occasions of experience. That our tasks as human beings is to develop this understanding and act from it, or face the consequences in our own physiology. Our birthright is the freedom and deep consciousness inherent in the "trillion billion senses" available to us and not the five or six as conventional wisdom would have it.

McClure's rich imagery can be, in part, traced back to the Pound/Williams School of North American poetry, in which "direct treatment of the thing, or object" or "no ideas but in things" is a standard mode of operation. But McClure goes beyond this rich phenomenological foundation. As you can see, McClure's gesture is not a rejection of the world, but a sensual embrace of all of it, even the most ghastly and aberrant aspects of life in this third millennium. Back to Cook:

On the contrary, the effort of self-transcendence, by which egotism, pride, and delusion are destroyed, is accompanied by a parallel immersion even more deeply than before into the concrete world of things. Rather than banish things as unworthy, such a vision reinstates the common and ordinary (as well as the "horrible" and "disgusting") to a position of ultimate value. The Hua-yen vision thus entails both a loss and a gain. The loss is the loss of the intruding self, which will not let things be what they are. The gain is the new ability to see that everything is wonderful and good. (Cook 1994, pp. 88-89) 
In this way, McClure's poetry acts like Hua-yen does, as a lure attracting the aspirant (or potential aspirant) to a practice which validates the theory of interconnectedness. One can get there by many paths, as the "truth is a pathless land" as Krishnamurti said. Meditation, which McClure begrudgingly began to practice late in life, is one method. But his writing process, Projective Verse, is another, as he practices it. This spontaneous, free-associative method, practiced as a discipline, affords him the freedom to transcend self in the act of composing. This is similar to a method, which has a long and misunderstood history in Western poetry, and includes such practitioners as Caedmon, Rilke, Yeats (and his "spooks"), Olson, Spicer, Duncan, Blaser, early Levertov, George Bowering, Fred Wah and other poets.

Reality, in life, is a process, not a product. Western society is addled by the predominance of the "industry-generated-culture." This corruption of how culture works, seeking what it can take, rather than give, informs the majority of art in such countries as the United States and perpetuates a mechanistic/reductionistic cosmology. Consciousness is not something that happens in the brain like digestion happens in the stomach, as is the prevailing scientific model. Process is McClure's method. Each poem is an experiment in consciousness for him, a pleasant trip to a place he's never been before. Hence Olson's references to concepts like proprioception and prehension. He wanted verse to get back to the more immediate experience, rather than the through about the experience. In his novel Bass Cathedral, Nathaniel Mackey writes to the Angel of Dust saying, "It seems as if you've removed one wall ... between reflex and assignation" (Mackey 2010, p. 20). The consciousness of that immediate impulse is what McClure's after, not the assignation.

After nearly sixty years of practice the distance IS closed in McClure's work and anyone seeking a deeper experience with life, via a close reading of his poetry. There is a suppleness, awareness of biology, a physicality present in his work unlike anything else out of Twentieth century North American poetry. This quality permeates everything McClure does and in getting to know his work better we do become "free of ligaments and tendencies to change myself into a shape that's less than spirit" (McClure 1983, p. 47).

He has created a window for anyone open enough to perceive and enter. A window beckoning those consumed with their own entelechy, with an aural imagination (or potential to develop one) and a dedication to carry it out and create their own luminous field. It is an entrance to a deeper and more satisfying experience with being human, not power over; an effort so critical in a culture that suffers from the motivation of corporations. After all, we are our language. We live and die based on our ability to articulate. And speech in our culture has become corrupted by the forces that do seek power over. Future historians will understand this quite clearly and understand this process and McClure's use of it as one of the great lights in a very dark time. It is a road map to the luminous in an era where the darkness appears overwhelming.

Funding: This research received no external funding.

Conflicts of Interest: The author declares no conflict of interest.

\section{References}

Blaser, Robin. 2006. The Fire: Collected Essays. Berkeley: University of California.

Bram, Shahar. 2004. Charles Olson and Alfred North Whitehead: An Essay on Poetry. Lewisburg: Bucknell University Press. Cook, Francis. 1994. Hua-Yen Buddhism: The Jewel Net of Indra. Dehli: Sui Satguru Publications.

Duncan, Robert, and Denise Levertov. 2004. The Letters of Robert Duncan and Denise Levertov. Edited by Robert J. Bertholf and Albert Gelpi. Stanford: Stanford University Press.

Ginsberg, Allen. 1994. Mind Writing Slogans. In Waldman, Anne and Schelling, Andrew. Edited by Disembodied Poetics. Albuquerque: University of New Mexico.

Hrebeniak, Michael. 2006. Action Writing. Chicago: SIU Press.

Kerouac, Jack. 1995. Desolation Angels. New York: Riverhead.

Mackey, Nathaniel. 2010. Bass Cathedral. New York: New Directions. 
Mariani, Paul. 1982. William Carlos Williams: A New World Naked. New York: McGraw Hill.

McClure, Michael. 1983. Fragments of Perseus. New York: New Directions.

McClure, Michael. 1994. Scratching the Beat Surface. New York: Penguin Books.

McClure, Michael. 1995. Three Poems. New York: Penguin Books.

McClure, Michael. 2010. Mysteriosos and Other Poems. New York: New Directions.

O’Leary, Peter. 2002. Gnostic Contagion. Middletown: Wesleyan University Press.

Olson, Charles. 1997. Collected Prose. Berkeley: University of California.

Sheldrake, Rupert. 2003. The Sense of Being Stared At. New York: Crown.

von Hallberg, Robert. 1978. Charles Olson: The Scholar's Art. Cambridge: Harvard University Press.

C 2018 by the author. Licensee MDPI, Basel, Switzerland. This article is an open access article distributed under the terms and conditions of the Creative Commons Attribution (CC BY) license (http://creativecommons.org/licenses/by/4.0/). 